\title{
Recent Progress in the Use of Glucagon and Glucagon Receptor Antago- nists in the Treatment of Diabetes Mellitus
}

\author{
Mohamed Lotfy ${ }^{1}$, Huba Kalasz ${ }^{2}$, Gyorgy Szalai ${ }^{3}$, Jaipaul Singh $^{4}$ and Ernest Adeghate ${ }^{5, *}$
}

${ }^{I}$ Department of Biology, College of Science, United Arab Emirates University; School of Forensic and Investigative Sciences, University of Central Lancashire, Preston PR1 2HE, England, UK; National Research Centre, Hormones Department, Cairo, Egypt; ${ }^{2}$ Department of Pharmacology and Pharmacotherapy, Semmelweis University, Budapest, Hungary; ${ }^{3}$ ENT Department, St. Janos Hospital, Budapest, Hungary; ${ }^{4}$ School of Forensic and Investigative Sciences and School of Pharmacy and Biomedical Science, University of Central Lancashire, Preston PRI 2HE, England, UK; ${ }^{5}$ Department of Anatomy, College of Medicine \& Health Sciences, United Arab Emirates University, Al Ain, United Arab Emirates.

\begin{abstract}
Glucagon is an important pancreatic hormone, released into blood circulation by alpha cells of the islet of Langerhans. Glucagon induces gluconeogenesis and glycogenolysis in hepatocytes, leading to an increase in hepatic glucose production and subsequently hyperglycemia in susceptible individuals. Hyperglucagonemia is a constant feature in patients with T2DM. A number of bioactive agents that can block glucagon receptor have been identified. These glucagon receptor antagonists can reduce the hyperglycemia associated with exogenous glucagon administration in normal as well as diabetic subjects. Glucagon receptor antagonists include isoserine and beta-alanine derivatives, bicyclic 19-residue peptide BI-32169, Des-His1-[Glu9] glucagon amide and related compounds, 5-hydroxyalkyl-4-phenylpyridines, N-[3-cano-6(1,1 dimethylpropyl)-4,5,6,7-tetrahydro-1-benzothien-2-yl]-2-ethylbutamide, Skyrin and NNC 250926. The absorption, dosage, catabolism, excretion and medicinal chemistry of these agents are the subject of this review. It emphasizes the role of glucagon in glucose homeostasis and how it could be applied as a novel tool for the management of diabetes mellitus by blocking its receptors with either monoclonal antibodies, peptide and non-peptide antagonists or gene knockout techniques.
\end{abstract}

Keyword: Diabetes mellitus, glucagon, glucagon receptor antagonists, pancreas.

\section{INTRODUCTION}

Glucagon is a hormone made up of 29 amino acids. It is formed from pro-glucagon precursor. Proglucagon is proteolytically processed into various peptide hormones such as glucagon in pancreatic alpha cell, glucagon like peptide-1 (GLP-1), GLP-2, oxyntomodulin and glicentin in intestinal L cells and the central nervous system [1]. Diabetes mellitus (DM) is characterized by chronic increment of fasting blood glucose level associated with marked and sustained postprandial hyperglycemia. At the same time, type 2 diabetes mellitus (T2DM) is associated with a disturbed secretion and function of several pancreatic hormones including insulin and glucagon all of which play an essential role in glucose homeostasis. T2DM is associated, especially in late stage, with a deficiency in insulin secretion and impairment in the ability of insulin to trigger its receptors effectively and help in the uptake of glucose into specific cells. The deficiency of insulin secretion and insulin resistance are correlated with reduction of glucose uptake in certain cells such as those of skeletal muscle. This condition is associated with hyperproliferation of pancreatic, glucagon secreting alpha cells resulting in hyperglucagonemia [2-4]. Several modified molecules

*Address correspondence to this author at the Department of Anatomy, College of Medicine \& Health Sciences, United Arab Emirates University, P.O Box 17666, Al Ain, United Arab Emirates; Tel: +971-3-7137496;

Fax: +971-3-7672033; E-mail: eadeghate@uaeu.ac.ae of glucagon have been shown to inhibit the function of glucagon receptors, thereby preventing the hyperglucagonemiainduced hyperglycemia seen in DM [3,5]. Insulin itself is a glucagon antagonist, inhibiting glucagon secretion via the activation of GABA receptor and its translocation to the cell membrane to prevent glucagon release [6]. The low insulin level observed in diabetic patients will result in high level of glucagon because of loss of insulin-induced glucagon inhibition.

Glucagon receptor belongs to the B-family of the transmembrane receptors called G-protein- coupled receptor (GPCR) [7]. The receptors responsible for the function of key bioactive agents such as GLP-1 and GLP-2, and glucosedependent insulinotropic peptide (GIP) are active members of this group of receptors as well [8].

Glucagon promotes glucose production from the liver, mainly via binding with the G-protein coupled glucagon receptor to stimulate gluconeogenesis and glycogenolysis through the adenylate cyclase that initiates protein kinase A (PKA) activity. Simultaneously, PKA suppresses glycogen synthesis and glycolysis and induces ketogenesis [9]. Glucagon also initiates lipolysis in the liver and adipose tissues [10]. Glucagon receptors are expressed not only in the liver but also in many other tissues such as heart, smooth muscle of the intestine, brain, kidney and adipose tissues [11]. 


\section{GLUCAGON AND DIABETES}

The hormone glucagon plays a major role in the initiation and elevation of hyperglycemia in DM. Insulin and glucagon antagonize each other in the regulation of glucose level. In DM the blood plasma ratio of glucagon versus insulin levels in the blood plasma is higher than that observed in healthy controls. Although previous studies have reported that diabetic patients have significant reduction in the number of glucagon receptors, however, the effect of this peptide hormone at its receptor sites and the ability to activate cAMP remains largely intact [12]. This is probably due to the fact that the activation of $20 \%$ of glucagon receptors is enough to significantly stimulate adenylate cyclase [13]. Type 1 and 2 DM are associated with hyperglycemia, due in part to lack of suppression of glucagon release because of insulin loss [9, 14].

\section{GLUCAGON RECEPTOR}

The binding of glucagon to its GPCR, located on the plasma membrane results in conformational alterations in the nature of GPCR. The Gas and Gaq subunits of GPCR play an important role in glucagon-induced cell signaling in selected cells. Activation of Gas receptor induces large and significant increases in adenyl cyclase, and consequently in the cytoplasmic levels of cAMP and PKA. Moreover, stimulation of $\mathrm{G \alpha q}$ induces large increases in the level of phospholipase C, synthesis of inositol 1,4,5-triphosphate, followed by the release of calcium ion intracellularly, leading to glucose release from hepatocytes through initiation of glycogenolysis, gluconeogenesis and glycolysis and suppression of glycogenesis [15]. Abolition of glucagon receptors $(\mathrm{Gcgr}-\mathrm{-}-)$ leads to reduction in plasma glucose levels [16].

\section{GLUCAGON RECEPTORS IN THE TREATMENT OF DIABETES}

The pathogenic symptoms of DM, such as hyperglycemia and ketoacidosis are mainly due to the excessive circulating glucagon levels, while deficient insulin level or insulin resistance leads to decreased uptake of glucose. This physiological role of glucagon encourages many investigators to focus on putative glucagon antagonists to restore normoglycemia in patients suffering from DM. In view of this, glucagon receptor antagonists or molecules that could suppress the expression of glucagon receptors have attracted the attention of investigators working on the treatment of DM [17].

\section{GLUCAGON RECEPTOR GENE KNOCKOUT AS A TOOL FOR VALIDATING THIS RECEPTOR AS A POTENTIAL DRUG TARGET}

The fact that glucagonemia is not a good sign in DM has prompted investigators to try and block glucagon receptors on hepatic cells. This idea has stimulated scientists to construct mice lacking glucagon receptors Gcgr-/-. The inability of Gcgr-/- mice to develop hyperglycemia have supported the role of glucagon and its receptors in the pathogenesis of diabetes-induced hyperglycemia. Glucagon receptor gene knockout Gcgr-/- mice under normal diet showed a decreased blood glucose level. This Gcgr-/- mice also resist streptozotocin-induced hyperlycemia and show less beta cell damage [18]. In other studies, blocking of glucagon action (absence of glucagon receptor) in Gcgr-/- streptozotocininduced diabetic mice leads to enhancement of metabolic state and this finding indicates that glucagon receptor gene deletion in type 1 diabetic mice restores its normal metabolism [19]. Fasted Gcgr-/- mice also showed a decrease in blood glucose level but not an overt hypoglycemia, because increase in blood glucose is not regulated by glucagon alone but also by several other hormones including catecholamines, corticosteroids and growth hormone [20]. However, fasted Gcgr $-/-$ mice showed considerable deficiency in lipid production, secretion, and oxidation [21]. This result indicates that a minimal essential level of glucagon receptor expression is needed to maintain normal lipid metabolism in the liver [21]. In contrast, other studies have shown that the level of lipids is normal in the presence of lower glucagon receptor level [22].

Gcgr-/- mice were characterized by enhanced glucose tolerance and associated with increased GLP-1 plasma concentrations. This elevation of GLP-1 is mainly produced by alpha cells [16]. The improvement of glucose homeostasis in these Gcgr-/- mice resulted mainly from either suppression of glucagon signaling or increased secretion of GLP-1 [23].

Suppression of liver Gcgr expression was seen after treatment of $\mathrm{db} / \mathrm{db}$ mice with antisense oligonucleotide. Reduction of liver Gcgr expression was associated with decreased blood glucose concentration, plasma free fatty acids and triglycerides with undetected hypoglycemia [24].

In addition, Gcgr antisense oligonucleotide administration to ob/ob and $\mathrm{db} / \mathrm{db}$ mice and Zucker diabetic fatty rats showed a reduction of both blood glucose levels and liver triglycerides. Also, treatment of rodents via Gcgr antisense oligonucleotide leads to increased blood concentration of glucagon and GLP-1 with hyperproliferation of alpha cells [25]. This investigation in rodents revealed that the suppression of Gcgr expression and glucagon effect lead to a reduction of liver glucose output with enhanced glucose tolerance [26].

Gcgr-/ - mice of either streptozotocin-provoked or highfat diet treated has been investigated. The results of glucagon receptor deletion mice compared to normal control mice had showed that Gcgr-/- mice were characterized by reduced body weight, appetite and gastric motility with decreased blood glucose concentrations and enhanced glucose homeostasis. In addition, Gcgr-/- mice showed decreased hyperleptinaemia and liver steatosis induced by high-fat diet and less susceptible hyperglycemia in streptozotocin-induced beta cell damage [18].

Prominent alpha cell hyperplasia and elevated blood glucagon levels were seen in Gcgr-/- mice as a compensatory effect due to deletion of Gcgr. Moreover, a reduction in free fatty acid and $\beta$-hydroxybutyrate concentrations were seen in Gcgr-/- mice [19].

\section{ANTIBODY NEUTRALIZATION OF GLUCAGON}

Many investigators have reported that suppression of glucagon action causes considerable improvement in elevated blood glucose concentrations in animal models of DM. Immunoneutralization of glucagon by monoclonal antibody in diabetic rats, mice and rabbits lead to a significant de- 
crease in blood glucose levels. Moreover, there was a significant reduction in serum levels of glycosylated hemoglobin Alc and serum triglyceride in ob/ob mice treated with glucagon antibodies [18-21]. In addition, glucagon antibodies significantly decrease the output of glucose from the liver, which in turn reduces the elevated blood glucose levels in diabetic and normal rabbits [20]. Other studies reported that glucagon immunoneutralization leads to a marked decrease in glucagon levels and improve glucose tolerance in experimental animals $[18,19]$. It is clear from these studies that immunoneutralization of glucagon may be a promising tool for the treatment of DM (Table 1).

\section{PEPTIDE ANTAGONISTS OF GLUCAGON RECEP- TORS}

Glucagon antagonists inhibit both glucagon receptors binding and the action of glucagon at the receptor binding site. Some glucagon antagonists may inhibit glucagon action via competitive or noncompetitive pathways [31,32]. Glucagon receptors show species specificity as some of them are more effective on human glucagon receptor than those of rodents [33]. According to many reports, experimental animal expressing receptors similar to those of human will be a potent tool to demonstrate the in vivo estimation of the effectiveness of glucagon receptor antagonists in the treatment of human DM [34].

Many recent studies were directed towards the discovery of new ways of suppressing glucagon action using glucagon receptor antagonists with a strong binding activity towards glucagon receptors than the native glucagon [35-37]. The administration of glucagon receptor antagonists leads to a reduction in blood glucose levels in normal and diabetic rodent models [38-40]. A number of glucagon antagonists have recently been reported. Many studies were focused on the discovery of glucagon peptide derivatives of potent glucagon receptor antagonist through the modification of different amino acids moiety in native glucagon hormone. Many glucagon derivatives studied include His1, Phe6, Ser8, Asp9, Tyr10, Ser11, Lys12, Tyr13, Asp15, Ser16, Arg17,18, Asp21 and Trp25 [41] and bicyclic 19-residue peptide BI32169, Des-His(1)-[Glu(9)]-glucagon amide. This naturally occurring peptide was isolated from Streptomyces sp [42]. Administration of this bicyclic 19-residue peptide BI-32169 showed a strong reduction in human glucagon receptor activity in a cell-based experiment [43]. Bicyclic 19-residue peptide BI-32169 novel peptide is considered to belong to the lasso group. The potential advantage of this compound is the fact that it is a naturally occurring substance (Table 2).

Many investigators have tried to design a glucagon receptor antagonist by modifying the sequence of its amino acid. The des-His(1)-[Glu(9)]-glucagon amide is an outcome of this endeavor. The glucagon receptor antagonist desHis(1)-[Glu(9)]-glucagon amide was reported to totally abolish the activity of glucagon receptor and leads to a reduction in hyperglycemia in normal rabbits and in streptozotocininduced diabetic rats when administered intravenously [43, 44]. Des-His-glucagon, a peptidyl glucagon receptor antagonist, binds to about $80 \%$ of the mice liver glucagon receptors and prevents the increase in glucagon-induced plasma glucose [39]. Other glucagon receptor antagonist [1natrinitrophenylhistidine, 12-homoarginine]-glucagon showed a marked reduction (20-35\%) of blood glucose levels in streptozotocin-induced diabetic rats when given intravenously [40]. Similar antagonistic effect was reported by [des-His, des Phe(6),Glu(9)]-glucagon-NH2, which also has hypoglycemic effect. $750 \mu \mathrm{g} / \mathrm{Kg}$ body weight induced up to $63 \%$ decrease in the level of hyperglycemia, when given intravenously [45] (Table 2).

\section{NON-PEPTIDE GLUCAGON RECEPTOR ANTAGO- NISTS}

Many orally administered doses of small molecules such as ureas, beta-alanine derivatives, alkylidene hydrazides and benzimidazole were reported to be able to block glucagon receptor in both non-diabetic and diabetic dogs, and monkeys [38-40]. Recent studies have shown that beta-alanine urea derivatives can block glucagon from binding to human glucagon receptor when given intragastricaly at a dose of 20$100 \mathrm{mg} / \mathrm{kg}$ [46, 47]. Beta alanine, also known as 3aminopropanoic acid, is a non-essential amino acid that is frequently used by sportsmen to enhance their performance. (+)-3,5 diisopropyl-2-(1-hydroxyethyl)-6-propyl-4'-fluoro1,1'- biphenyl; C23H31FO) (Bay 27-9955) is a small nonpeptide glucagon receptor antagonist, which has been reported to prevent hyperglucagonemia when administered intravenously at a dose of 70-200 mg. However, Bay 279955 can also be given orally. It prevents glucagon-induced increase in glucose release from the human liver in a dosedependent way [48]. See Fig. (1) for the structure of some selected glucagon receptor antagonists.

One of the other non-peptide glucagon receptor antagonists is a 5-hydroxyalkyl-4- phenylpyridines which has about 70-fold more binding capacity to the human glucagon receptor compared to wild glucagon hormone [49]. In addition, compound-1 (Cpd1) is one of the most effective glucagon receptor antagonists that can bind glucagon in human liver cells. Cpd1 also leads to a reduction in glucagon-stimulated glucose increase in mice liver when given intraperitoneally, at a dose of $15 \mathrm{mg} / \mathrm{Kg}$ body weight. Cpd1 is an effective tool in the reduction of hepatic glucose release and decreasing hyperglycemia in type 2 DM [50].

Skyrin, a fungal product, is a low molecular weight nonpeptide glucagon receptor antagonists which does not bind to glucagon receptors but act only as an inhibitor of glucagonstimulated cAMP activation and glycogenolysis, via uncoupling or disconnect the glucagon receptor from adenylate cyclase activation, thus preventing the glucagon receptor from the production of cAMP that inhibits glucose release from the liver. The effective dose of skyrin is $10-30 \mathrm{mM}$ [51].

In addition to skyrin, other agents including $\mathrm{N}$-[3-cano6-(1,1-dimethylpropyl)-4,5,6,7-tetrahydro-1-benzothien-2-yl]2-ethylbutamide, has been examined. It was shown that N-[3-cano-6-(1,1-dimethylpropyl)-4,5,6,7-tetrahydro-1-benzothien-2-yl]-2-ethylbutamide inhibits the attachment and function of the glucagon-receptor complex thereby suppressing the action of glucagon at $15 \mu \mathrm{g}$ (i.p.) and act as glucagon receptor antagonists [50]. Compounds such as (2R)-N-[4(\{4-(1-cyclohexen-1-yl)[(3,5-dichloroanilino) carbonyl] anilino $\}$ methyl) benzoyl]-2-hydroxy-balanine, (NNC 250926) has been shown to inhibit hepatic production of 
Table 1. The use of immunoneutralization of glucagon receptors by monoclonal antibody.

\begin{tabular}{|c|c|c|}
\hline Dosage & 1 - $30 \mathrm{mg} / \mathrm{kg}$ (monoclonal antibody) & References \\
\hline Mode of delivery & Subcutaneous (s.c.) & \\
\hline
\end{tabular}

Table 2. Peptide antagonists of glucagon receptors.

\begin{tabular}{|c|c|c|c|c|}
\hline & Dosage & Mode of Delivery & Efficacy & References \\
\hline \hline $\begin{array}{c}\text { Bicyclic 19-residue peptide } \\
\text { BI-32169 }\end{array}$ & $320-440 \mathrm{nM}$ & $\begin{array}{c}\text { Subcutaneous (s.c.) or } \\
\text { intravenous (i.v.) }\end{array}$ & Investigations still in the experimental phase. & [42, 43] \\
\hline $\begin{array}{c}\text { Des-His(1)-[Glu(9)]- } \\
\text { glucagon amide }\end{array}$ & $10 \mu \mathrm{g}$ & Intravenously (i.v.) & $\begin{array}{c}\text { Single dose blocks up to 40-80\% of endo- as well } \\
\text { as exogenous glucagon, including free as well as } \\
\text { hepatocyte-bound. }\end{array}$ & \begin{tabular}{c}
{$[39,40,43-45]$} \\
\hline
\end{tabular}
\end{tabular}

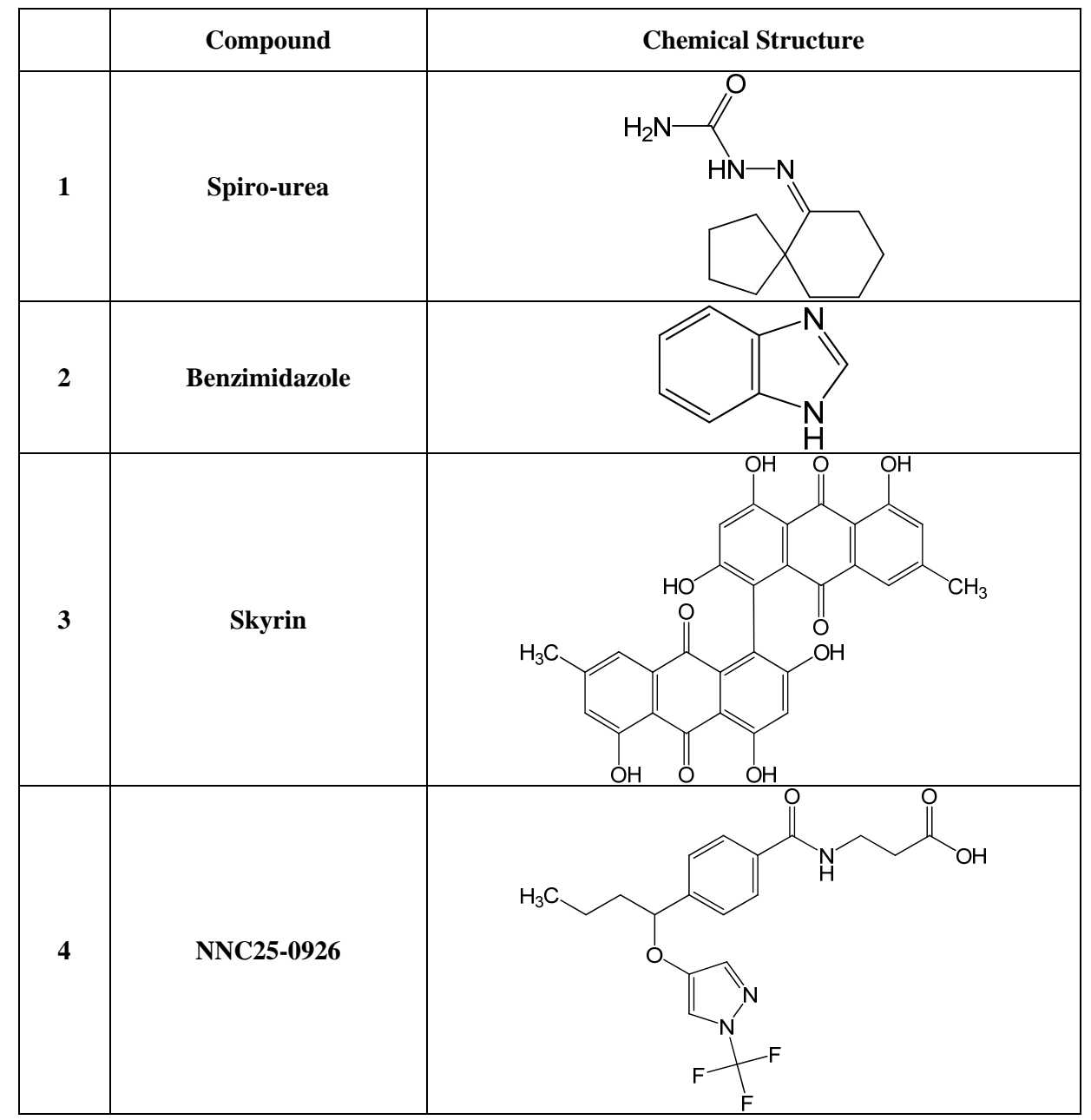

Fig. (1). Chemical structure of selected glucagon and/or glucagon receptor antagonists.

glucose when administered at a dose of between 10 and 100 $\mathrm{mg} / \mathrm{Kg}$ body (intragastrically). See Fig. (1) for the structure of selected glucagon receptor antagonists.
A study of the activity of urea biaryl amide derivative $6 \mathrm{i}$ as glucagon receptor antagonist on Sprague-Dawley rats has showed $50 \%$ inhibition of glucagon action on glucose liver 
output under glucagon challenge [52]. Similarly, a spiroureas substitution, compound 15 , has revealed as inhibitory action as glucagon receptor antagonist on genetically modified mice expressing human glucagon receptor with moderate reduction of hyperglycemia provoked by glucagon [53]. In a related study, a trisubstituted urease derivative, compound $4 \mathrm{a}$, has demonstrated its potent suppression of glucagon receptor action in glucagon-challenged mice expressing human glucagon receptor. This treatment leads to lowering plasma glucose concentrations under high lipid diet [54].

A 1,3,5-pyrazoles substitution, compound 26, has showed a strong glucagon receptor antagonists on rhesus monkey and mice expressing human glucagon receptor. Orally administered compound 26 reduced the hyperglycemia under glucagon effect [55].

Oral effective aminobenzimidazole glucagon receptor antagonist has been established as a glucagon suppressor drug. Aminobenzimidazole showed reducing effect on glucose concentrations in glucagon-induced murine diabetic model, rhesus monkeys, and genetically modified human glucagon receptor mice [56].

A study of the pharmacodynamics effect of orally $\beta$ alanine derivatives as glucagon receptor antagonists lead compound 25 and the optimized derivative 57 had revealed that they suppressed the glucagon-challenged hyperglycemia in rats mainly through reduction of glucagon action on liver glucose production [57].

A promising glucagon receptor antagonist compound 15 is derived from $\beta$-alanine series by changing the $\beta$-alanine motif to isoserine. Compound 15 has confirmed as suppressor glucose output under glucagon-challenge from rat liver cells. In addition, compound 15 reduced hyperglycemia in Sprague-Dawley rats and in ob/ob mouse [46].

Epigenetic changes occur via a variety of mechanisms including, chromosome conformational modification, histone alteration, other DNA-associated proteins and non-coding RNAs [58].

Epigenetic alterations may be caused by methylation of chromosomes. This in turn may either activate or suppress relevant genes [59]. Other ways in which epigenetic variation may occur is by histone post-translation alterations such as acetylation, citrullination, cutting, methylation, phosphorylation and ubiquitination [58]. Alterations in histone structure can change the way that histone binds or interacts with other proteins that modify transcriptional mechanism [60]. Furthermore, non-coding RNAs association with DNA can change chromosomal structure eventually leading to alterations in post-translational gene expression [61].

Chromosomal alterations may contribute to epigenetic variants that are involved in genomic modifications associated with some cancers and others diseases [62]. It has been shown that epigenetic chromosomal methylation influences type 1 diabetes via alteration of insulin and interleukin genes [60]. Epigenetic changes leading a decrease in the gene expression of either Glut4 or Pdx-1 has been observed in T2DM [63-65]. Moreover, it has been shown that chromosomal modification accompanied with histone acetylation can cause the progression of DM and thus, the use of histone deacetylase inhibitors as an epigenetic therapy can suppress

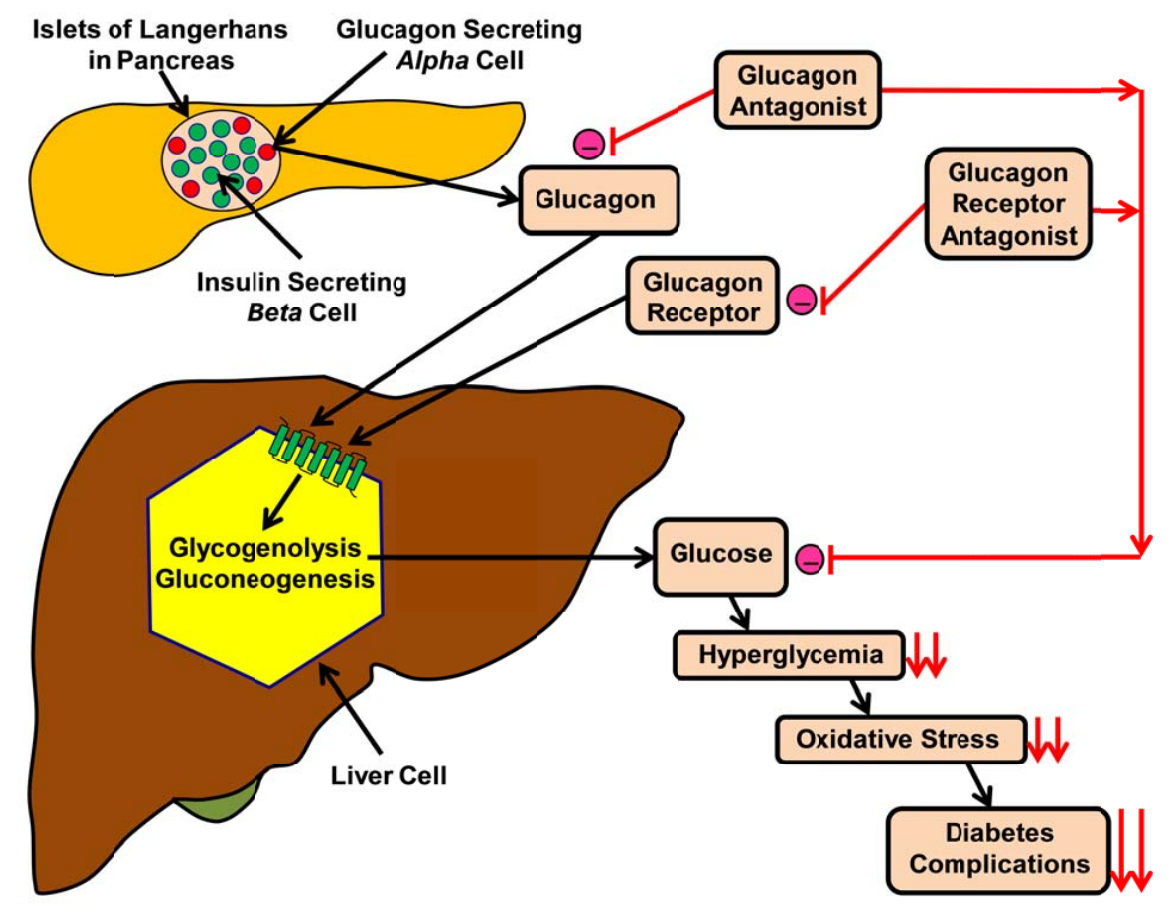

Fig. (2). Effects of either glucagon or glucagon receptor antagonist on reduction of diabetic complications.

Fig. (2). shows how a schematic diagram of interaction between glucagon, glucagon antagonist, glucagon receptor antagonist and glycogenolysis in the regulation of blood glucose level. (-) = inhibition, $=\downarrow \downarrow$ reduction. 
Table 3. The advantages and disadvantages of glucagon neutralization and glucagon receptor antagonists.

\begin{tabular}{|c|c|c|c|}
\hline & Advantages & Disadvantages & References \\
\hline Neutralizing antibodies against glucagon & $\begin{array}{c}\text { Reduced hyperglycemia; lowers triglyceride } \\
\text { concentration }\end{array}$ & Weight gain & {$[22]$} \\
\hline Glucagon receptor antagonism & Decreased blood glucose concentrations & Abnormal lipid production & {$[16,21]$} \\
\hline
\end{tabular}

Table 4. The effect some glucagon receptor antagonists.

\begin{tabular}{|c|c|c|c|c|c|c|}
\hline Drug & Compound & Efficacy & Dosage & Adverse effect & $\begin{array}{l}\text { Clinical } \\
\text { phase }\end{array}$ & Ref \\
\hline Spiro-urea & Compound 15 & $\begin{array}{l}\text { (a)Reduced glucose excursion } \\
\text { after glucagon challenge ; (b) } \\
\text { blocks glucagon effect }\end{array}$ & 10 and $30 \mathrm{mg} / \mathrm{kg}$ (i.m.) & $\begin{array}{l}\text { thirst, dry mouth, nausea, } \\
\text { polyuria }\end{array}$ & Pre-clinical & {$[53,67]$} \\
\hline $\begin{array}{l}\text { Benzimi- } \\
\text { dazole }\end{array}$ & Compound 36 & $\begin{array}{l}\text { Reduced glucose levels in dia- } \\
\text { betes; suppressed glucagon- } \\
\text { induced glucose increase in } \\
\text { animals }\end{array}$ & $\begin{array}{c}10 \text { and } 3 \mathrm{mg} / \mathrm{kg} \text { in rhesus } \\
\text { monkeys }\end{array}$ & $\begin{array}{l}\text { Reduced human liver } \\
\text { microsome stability }\end{array}$ & Pre-clinical & {$[56,68]$} \\
\hline Skyrin & $\begin{array}{l}\text { Fungal bisan- } \\
\text { thro-quinone }\end{array}$ & $\begin{array}{l}\text { Antagonized functional gluca- } \\
\text { gon (uncouples glucagon recep- } \\
\text { tor from adenylate cyclase in } \\
\text { hepatocyte plasmalemma }\end{array}$ & $\begin{array}{c}30 \text { micromol/1 inhibited } \\
\text { glucagon-stimulated cAMP } \\
\text { production and glucose } \\
\text { output }\end{array}$ & $\begin{array}{c}\text { Suppressed } \mathrm{Na}^{+}, \mathrm{K}^{+}- \\
\text {activated ATPase; Inhibits } \\
\text { microsomal activity in rat } \\
\text { brain }\end{array}$ & $\begin{array}{l}\text { Not in } \\
\text { clinical } \\
\text { trial }\end{array}$ & {$[51,69]$} \\
\hline
\end{tabular}

the development of DM [66]. Other agents that prevent unwarranted DNA methylation and other molecular factors leading to epigenetic changes will be useful in the management of DM. In fact it has been reported that GLP-1 and GIP, molecules related to glucagon can overturn the epigenetic phenomenon in T2DM [64]. In fact it has been shown that GLP-1 and GIP act via GPCR, the receptor through which glucagon exerts its action [7].

\section{CONCLUSION}

Optimal management of diabetic patients using glucagon antagonist must avoid the adverse effects of this drug, such as hypoglycemia, liver stenosis, increases in liver enzymes, and disturbed lipid metabolism. Accordingly, reduction of blood glucagon level by using glucagon receptor antagonists must balance between therapeutic benefits and adverse effects.

This mini-review has shed light on the role of glucagon in the regulation of glucose metabolism and how it could be used as a tool for the treatment of DM either by using antagonists or gene knockout techniques that could neutralize the action of glucagon or blocking the binding of glucagon to its receptors with antibody immunization (Fig. $\mathbf{2}$ and Table 3) A summary of the efficacy, dosage, adverse effect and the status of some glucagon receptor antagonists is given in Table 4.

\section{CONFLICT OF INTEREST}

The authors confirm that this article content has no conflict of interest.

\section{ACKNOWLEDGEMENTS}

Declared none.

\section{PATIENT'S CONSENT}

Declared none.

\section{REFERENCES}

[1] Baggio, L.L.; Drucker, D.J. Biology of incretins: GLP-1 and GIP Gastroenterol., 2007, 132, 2131-57.

[2] Duffy, J.L.; Kirk, B.A.; Konteatis, Z.; Campbell, E.L.; Liang, R.; Brady, E.J.; Candelore, M.R.; Ding, V.D.; Jiang, G.; Liu, F.; Qureshi, S.A.; Saperstein, R.; Szalkowski, D,; Tong, S.; Tota, L.M.; Xie, D,; Yang, X.; Zafian, P.; Zheng, S.; Chapman, K.T.; Zhang, B.B.; Tata, J.R. Discovery and investigation of a novel class of thiophene-derived antagonists of the human glucagon receptor. Bioorg. Med. Chem. Lett., 2005, 15, 1401-05.

[3] Al-Shamsi, M.; Amin, A.; Adeghate, E. Vitamin E decreases the hyperglucagonemia of diabetic rats. Ann. NY Acad. Sci., 2006, 1084, 432-41.

[4] Ponery, A.S.; Adeghate, E. Distribution of NPY and SP and their effects on glucagon secretion from the in vitro normal and diabetic pancreatic tissues. Peptides, 2000, 21 (10), 1503-09.

[5] Quesada, I.; Tuduri, E.; Ripoll, C.; Nadal, A. Physiology of the pancreatic alpha-cell and glucagon secretion: role in glucose homeostasis and diabetes. J. Endocrinol., 2008, 199, 5-19.

[6] Xu, E.; Kumar, M.; Zhang, Y.; Ju, W.; Obata, T.; Zhang, N.; Liu, S.; Wendt, A.; Deng, S.; Ebina, Y.; Wheeler, M.B.; Braun, M.; Wang, Q. Intra-islet insulin suppresses glucagon release via GABA-GABA(A) receptor system. Cell Metab. 2006, 3, 47-8.

[7] Pierce, K.L.; Premont, R.T.; Lefkowitz, R.J. Seven transmembrane receptors. Nat. Rev. Mol. Cell Biol., 2002, 3, 639-50.

[8] Lok, S.; Kuijper, J.L.; Jelinek, L.J.; Kramer, J.M.; Whitmore, T.E.; Sprecher, C.A.; Mathewes, S.; Grant, F.J.; Biggs, S.H.; Rosenberg, G.B. The human glucagon receptor-encoding gene: structure, cDNA sequence and chromosomal localization. Gene, 1994, 140(2), 203-09.

[9] Shah, P.; Vella, A.; Basu, A.; Basu, R.; Schwenk, W.F.; Rizza, R.A. Lack of suppression of glucagon contributes to postprandial hyperglycemia in subjects with type 2 diabetes mellitus. J. Clin. Endocrinol. Metab., 2000, 85, 4053-59.

[10] McGarry, J.D.; Foster. D.W. Regulation of hepatic fatty acid oxidation and ketone body production. Annu. Rev. Biochem., 1980, 49 , 395-20. 
[11] Hansen, L.H.; Abrahamsen, N.; Nishimura, E. Glucagon receptor mRNA distribution in rat tissues. Peptides, 1995, 16, 1163-66.

[12] Burcelin, R.; Katz, E.B.; Charron, M.J. Molecular and cellular aspects of the glucagon receptor: role in diabetes and metabolism. Diabetes Metab., 1996, 22, 373-96.

[13] Birnbaumer, L.; Pohl, S.L.; Rodbell, M. The glucagon-sensitive adenylate cyclase system in plasma membranes of rat liver. VII. Hormonal stimulation: reversibility and dependence on concentration of free hormone. J. Biol. Chem., 1972, 247, 2038-43.

[14] Shah, P.; Basu, A.; Basu, R.; Rizza, R. Impact of lack of suppression of glucagon on glucose tolerance in humans. Am. J. Physiol. Endocrinol. Metab., 1999, 277, E283-90.

[15] Jiang, G.; Zhang, B.B. Glucagon and regulation of glucose metabolism. Am. J. Physiol. Endocrinol. Metab., 2003, 284, E671-78.

[16] Gelling, R.W.; Du, X.Q.; Dichmann, D.S.; Romer, J.; Huang, H.; Cui, L.; Obici, S.; Tang, B.; Holst, J.J.; Fledelius, C.; Johansen, P.B.; Rossetti, L.; Jelicks, L.A.; Serup, P.; Nishimura, E.; Charron, M.J. Lower blood glucose, hyperglucagonemia, and pancreatic alpha cell hyperplasia in glucagon receptor knockout mice. Proc. Natl. Acad. Sci. USA, 2003, 100, 1438-43.

[17] Zhang, B.B.; Moller, D.E. New approaches in the treatment of type 2 diabetes. Curr. Opin. Chem. Biol., 2000, 4, 461-67.

[18] Conarello, S.L.; Jiang, G.; Mu, J.; Li, Z.; Woods, J.; Zycband, E.; Ronan, J.; Liu, F.; Roy, R.S.; Zhu, L.; Charron, M.J.; Zhang, B.B. Glucagon receptor knockout mice are resistant to diet-induced obesity and streptozotocin-mediated beta cell loss and hyperglycaemia. Diabetologia, 2007, 50, 142-50.

[19] Lee, Y.; Wang, M-Y.; Du, X.Q.; Charron, M.J.; Unger, R.H. Glucagon Receptor Knockout Prevents Insulin-Deficient Type 1 Diabetes in Mice. Diabetes, 2011, 60, 391-97.

[20] Parker, J.C.; Andrews, K.M.; Allen, M.R.; Stock, J.L.; Mc-Neish, J.D. Glycemic control in mice with targeted disruption of the glucagon receptor gene. Biochem. Biophys. Res. Commun., 2002, 290, 839-43.

[21] Longuet, C.; Sinclair, E.M.; Maida, A.; Baggio, L.L.; Maziarz, M.; Charron, M.J.; Drucker, D.J. The Glucagon receptor is required for the adaptive metabolic response to fasting. Cell Metab., 2008, 8 , 359-71.

[22] Sorensen, H.; Brand, C.L.; Neschen, S.; Holst, J.J.; Fosgerau, K.; Nishimura, E.; Shulman, G.I. Immunoneutralization of endogenous glucagon reduces hepatic glucose output and improves long-term glycemic control in diabetic ob/ob mice. Diabetes, 2006, 55, 284348.

[23] Cho, Y.M.; Merchant, C.E.; Kieffer, T.J. Targeting the glucagon receptor family for diabetes and obesity therapy. Pharmacol. Ther., 2012, 135(3), 247-78.

[24] Liang, Y.; Osborne, M.C.; Monia, B.P.; Bhanot, S.; Gaarde, W.A.; Reed, C.; She, P.; Jetton, T.L.; Demarest, K.T. Reduction in glucagon receptor expression by an antisense oligonucleotide ameliorates diabetic syndrome in db/db mice. Diabetes, 2004, 53, 410-17.

[25] Sloop, K.W.; Cao, J.X.; Siesky, A.M.; Zhang, H.Y.; Bodenmiller, D.M.; Cox, A.L.; Jacobs, S.J.; Moyers, J.S.; Owens, R.A.; Showalter, A.D.; Brenner, M.B.; Raap, A.; Gromada, J.; Berridge, B.R.; Monteith, D.K.; Porksen, N.; McKay, R.A.; Monia, B.P.; Bhanot, S.; Watts, L.M.; Michael, M.D. Hepatic and glucagonlike peptide1 -mediated reversal of diabetes by glucagon receptor antisense oligonucleotide inhibitors. J. Clin. Invest., 2004, 113, 1571-81.

[26] Ali, S.; Drucker, D.J. Benefits and limitations of reducing glucagon action for the treatment of type 2 diabetes. Am. J. Physiol. Endocrinol. Metab., 2009, 296, E415-21.

[27] Brand, C.L.; Rolin, B.; Jørgensen, P.N.; Svendsen, I.; Kristensen, J.S.; Holst, J.J. Immunoneutralisation of endogenous glucagon with monoclonal glucagon antibody normalizes hyperglycaemia in moderately streptozotocin-diabetic rats. Diabetologia, 1994, 37, 98593.

[28] Brand, C.L.; Jørgensen, P.N.; Knigge, U.; Warberg, J.; Svendsen, I.; Kristensen, J.S.; Holst, J.J. Role of glucagon in maintanence of euglycemia in fed and fasted rats. Am. J. Physiol., 1995, 32, E46977.

[29] Brand, C.L.; Joergensen, P.N.; Svendsen, I.; Holst, J.J. Evidence for a major role for glucagon in regulation of plasma glucose in conscious, nondiabetic, and alloxan-induced diabetic rabbits. Diabetes, 1996, 45, 1076-83.

[30] Brand, C.L.; Hansen, B.; Gronemann, S.; Moysen, M.; Holst, J.J. Subchronic glucagon neutralisation improves diabetes in ob/ob mice. Diabetes, 2000, 49(S1), A81.
[31] Ling, A.; Hong, Y.; Gonzalez, J.; Gregor, V.; Polinsky, A.; Kuki, A.; Shi, S.; Teston, K.; Murphy, D.; Porter, J.; Kiel, D.; Lakis, J.; Anderes, K.; May, J.; Knudsen, L.B.; Lau, J. Identification of alkylidene hydrazides as glucagon receptor antagonists. J. Med. Chem., 2001, 44, 3141-49.

[32] Ling, A.; Plewe, M.; Gonzalez, J.; Madsen, P.; Sams, C.K.; Lau, J.; Gregor, V.; Murphy, D.; Teston, K.; Kuki, A.; Shi, S.; Truesdale, L.; Kiel, D.; May, J.; Lakis, J.; Anderes, K.; Iatsimirskaia, E.; Sidelmann, U.G.; Knudsen, L.B.; Brand, C.L.; Polinsky, A. Human glucagon receptor antagonists based on alkylidene hydrazides. Bioorg. Med. Chem., 2002, 12, 663-66.

[33] Cascieri, M.A.; Koch, G.E.; Ber, E.; Sadowski, S.J.; Louizides, D.; de Laszlo, S.E.; Hacker, C.; Hagmann, W.K.; MacCoss, M.; Chicchi, G.G.; Vicario, P.P. Characterization of a novel, nonpeptidyl antagonist of the human glucagon receptor. J. Biol. Chem., 1999, 274, 8694-97.

[34] Shiao, L.L.; Cascieri, M.A.; Trumbauer, M.; Chen, H.; Sullivan, K.A. Generation of mice expressing the human glucagon receptor with a direct replacement vector. Transgenic Res., 1999, 8, 295-02.

[35] Dharanipragada, R.; Trivedi, D.; Bannister, A.; Siegel, M.; Tourwe, D.; Mollova, N.; Schram, K.; Hruby, V.J. Synthetic linear and cyclic glucagon antagonists. Int. J. Pept. Protein Res., 1993, 42, 68-7.

[36] Hruby, V.J. Structure-conformation-activity studies of glucagon and semi-synthetic glucagon analogs. Mol. Cell Biochem., 1982, 44, 49-64.

[37] Hruby, V.J.; Gysin, B.; Trivedi, D.; Johnson, D.G. New glucagon analogues with conformational restrictions and altered amphiphilicity: effects on binding, adenylate cyclase and glycogenolytic activities. Life Sci., 1993, 52, 845-55.

[38] Dallas-Yang, Q; Shen, X.; Strowski, M.; Brady, E.; Saperstein, R.; Gibson, R.E.; Szalkowski, D.; Qureshi, S.A.; Candelore, M.R.; Fenyk-Melody, J.E.; Parmee, E.R.; Zhang, B.B.; Jiang, G. Hepatic glucagon receptor binding and glucose-lowering in vivo by peptidyl and non-peptidyl glucagon receptor antagonists. Eur. J. Pharmacol., 2004, 501, 225-34.

[39] Johnson, D.G.; Goebel, C.U.; Hruby, V.J.; Bregman, M.D.; Trivedi, D. Hyperglycemia of diabetic rats decreased by a glucagon receptor antagonist. Science, 1982, 215, 1115-6.

[40] Unson, C.G.; Gurzenda, E.M.; Merrifield, R.B. Biological activities of des His1[Glu9]glucagon amide, a glucagon antagonist. Peptides, 1989, 10, 1171-7.

[41] Ahn, J.M.; Medeiros, M.; Trivedi, D.; Hruby, V.J. Development of potent glucagon antagonists: structure-activity relationship study of glycine at position 4. J. Pept. Res., 2001, 58(2), 151-8.

[42] Potterat, O.; Wagner, K.; Gemmecker, G.; Mack, J.; Puder, C.; Vettermann, R.; Streicher, R. BI-32169, a Bicyclic 19-Peptide with Strong Glucagon Receptor Antagonist Activity from Streptomyces sp. J. Nat. Prod., 2004, 67(9), 1528-31.

[43] Knappe, T.A.; Linne, U.; Xie, X.; Marahiel, M.A. The glucagon receptor antagonist BI-32169 constitutes a new class of lasso peptides. FEBS Lett., 2010, 584, 785-9.

[44] Merlen, C.; Fabrega, S.; Desbuquois, B.; Unson, C.G.; Authier, F. Glucagon-mediated internalization of serine-phosphorylated glucagon receptor and Gsa in rat liver. FEBS Lett., 2006, 580, 5697-04.

[45] Van Tine, B.A.; Azizeh, B.Y.; Trivedi, D.; Phelps, J.R.; Houslay, M.D.; Johnson, D.G.; Hruby, V.J. Low level cyclic adenosine 3', 5'monophosphate accumulation analysis of [des-His1, des-Phe6, Glu9] glucagon-NH2 identifies glucagon antagonists from weak partial agonists/antagonists. Endocrinol., 1996, 137, 3316-22.

[46] Kodra, J.T.; Jørgensen, A.S.; Andersen, B.; Behrens, C.; Brand, C.L.; Christensen, I.T.; Guldbrandt, M.; Jeppesen, C.B.; Knudsen, L.B.; Madsen, P.; Nishimura, E.; Sams, C.; Sidelmann, U.G.; Pedersen, R.A.; Lynn, F.C.; Lau, J. Novel glucagon receptor antagonists with improved selectivity over the glucose-dependent insulinotropic polypeptide receptor. J. Med. Chem., 2008, 51(17), 5387-96.

[47] Rivera, N.; Everett-Grueter, C.A.; Edgerton, D.S.; Rodewald, T.; Neal, D.W.; Nishimura, E.; Larsen, M.O.; Jacobsen, L.O.; Kristensen, K.; Brand, C.L.; Cherrington, A.D. A Novel Glucagon Receptor Antagonist, NNC 25-0926, Blunts Hepatic Glucose Production in the Conscious Dog. J. Pharmacol. Exp. Ther., 2007, 321(2), 743-52.

[48] Petersen, K.F.; Sullivan, J.T. Effects of a novel glucagon receptor antagonist (Bay 27-9955) on glucagon-stimulated glucose production in humans. Diabetologia, 2001, 44, 2018-24. 
[49] Ladouceur, G.H.; Cook, J.H.; Doherty, E.M.; Schoen, W.R.; MacDougall, M.L.; Livingston, J.N. Discovery of 5-Hydroxyalkyl-4phenylpyridines as a New Class of Glucagon Receptor Antagonists. Bioorg. Med. Chem. Lett., 2002, 12, 461-4.

[50] Qureshi, S.A.; Candelore, M.R.; Xie, D.; Yang, X.; Tota, L.M.; Ding, VD-H.; Li, Z.; Bansal, A.; Miller, C.; Cohen, S.M.; Jiang, G.; Brady, E.; Saperstein, R.; Duffy, J.L.; Tata, J.R.; Chapman, K.T.; Moller, D.E.; Zhang, B.B. A Novel Glucagon Receptor Antagonist Inhibits Glucagon Mediated Biological Effects. Diabetes, 2004, 53, 3267-73.

[51] Parker, J.C.; McPherson, R.K.; Andrews, K.M.; Levy, C.B.; Dubins, J.S.; Chin, J.E.; Perry, P.V.; Hulin, B.; Perry, D.A.; Inagaki, T.; Dekker, K.A.; Tachikawa, K.; Sugie, Y.; Treadway, J.L. Effects of skyrin, a receptor-selective glucagon antagonist, in rat and human hepatocytes. Diabetes, 2000, 49, 2079-86.

[52] Kurukulasuriya, R.; Sorensen, B.K.; Link, J.T., Patel, J.R.; Jae, H.S.; Winn, M.X.; Rohde, J.R.; Grihalde, N.D.; Lin, C.W.; Ogiela, C.A.; Adler, A.L.; Collins, C.A. Biaryl amide glucagon receptor antagonists. Bioorg. Med. Chem. Lett., 2004, 14(9), 2047-50.

[53] Shen, D.M.; Zhang, F.; Brady, E.J.; Candelore, M.R.; Dallas-Yang, Q.; Ding, V.D.; Dragovic, J.; Feeney, W.P.; Jiang, G.; McCann, P.E.; Mock, S.; Qureshi, S,A.; Saperstein, R.; Shen, X.; Tamvakopoulos, C.; Tong, X.; Tota, L.M.; Wright, M.J.; Yang, X.; Zheng, S.; Chapman, K.T.; Zhang, B.B.; Tata, J.R.; Parmee, E.R. Discovery of novel, potent, and orally active spiro-urea human glucagon receptor antagonists. Bioorg. Med. Chem. Lett., 2005, 15(20), 4564-69.

[54] Liang, R.; Abrardo, L.; Brady, E.J.; Candelore, M.R.; Ding, V.; Saperstein, R.; Tota, L.M.; Wright, M.; Mock, S.; Tamvakopolous, C.; Tong, S.; Zheng, S.; Zhang, B.B.; Tata, J.R.; Parmee, E.R. Design and synthesis of conformationally constrained tri-substituted ureas as potent antagonists of the human glucagon receptor. Bioorg. Med. Chem. Lett., 2007, 17(3), 587-92.

[55] Shen, D.M.; Brady, E.J.; Candelore, M.R.; Dallas-Yang, Q.; Ding, V.D.; Feeney, W.P.; Jiang, G.; McCann, M.E.; Mock, S.; Qureshi, S.A.; Saperstein, R.; Shen, X.; Tong, X.; Tota, L.M.; Wright, M.J.; Yang, X.; Zheng, S.; Chapman, K.T.; Zhang, B.B.; Tata, J.R.; Parmee, E.R. Discovery of novel, potent, selective, and orally active human glucagon receptor antagonists containing a pyrazole core. Bioorg. Med. Chem. Lett., 2011, 21(1), 76-81.

[56] Kim, R.M.; Chang, J.; Lins, A.R.; Brady, E.; Candelore, M.R.; Dallas-Yang, Q.; Ding, V.; Dragovic, J.; Iliff, S.; Jiang, G.; Mock, S.; Qureshi, S.; Saperstein, R.; Szalkowski, D.; Tamvakopoulos, C.; Tota, L.; Wright, M.; Yang, X.; Tata, J.R.; Chapman, K.; Zhang, B.B.; Parmee, E.R. Discovery of potent, orally active benzimidazole glucagon receptor antagonists. Bioorg. Med. Chem. Lett., 2008, 18(13), 3701-05.

[57] Lau, J.; Behrens, C.; Sidelmann, U.G.; Knudsen, L.B.; Lundt, B.; Sams, C.; Ynddal, L.; Brand, C.L.; Pridal, L.; Ling, A.; Kiel, D.; Plewe, M.; Shi, S.; Madsen, P. New beta-alanine derivatives are orally available glucagon receptor antagonists. J. Med. Chem., 2007, 50(1), 113-28.

[58] Hamm, C.A.; Costa, F.F. The impact of epigenomics on future drug design and new therapies. Drug Discov Today, 2011, 16(13), 62635 .

[59] Lister, R.; Pelizzola, M.; Dowen, R.H.; Hawkins, R.D.; Hon, G.; Tonti-Filippini, J.; Nery, J.R.; Lee, L.; Ye, Z.; Ngo, Q-M.; Edsall, L.; Antosiewicz-Bourget, J.; Stewart, R.; Ruotti, V.; Millar, A.H.; Thomson, J.A.; Ren, B.; Ecker, J.R. Human DNA methylomes at base resolution show widespread epigenomic differences. Nature, 2009, 462(7271), 315-22.

[60] Ray-Gallet, D.; Almouzni, G. Nucleosome dynamics and histone variants. Essays Biochem., 2010, 48, 75-87.

[61] Costa, F.F. Non-coding RNAs, epigenetics and complexity. Gene, 2008, 410, 9-17.

[62] Pogribny, I.P.; Beland, F.A. DNA hypomethylation in the origin and pathogenesis of human diseases. Cell Mol. Life Sci., 2009, 66, 2249-61.

[63] Wang, Q.; Li, L.; Xu, E.; Wong, V.; Rhodes, C.; Brubaker, P.L. Glucagon-like peptide-1 regulates proliferation and apoptosis via activation of protein kinase B in pancreatic INS-1 beta cells. Diabetologia, 2004, 47(3), 478-87.

[64] Pinney, S.E.; Simmons, R.A. Epigenetic mechanisms in the development of type 2 diabetes. Trends Endocrinol. Metab., 2010, 21, 223-9.

[65] Evans-Molina, C.; Robbins, R.D.; Kono, T.; Tersey, S.A.; Vestermark, G.L.; Nunemaker, C.S.; Garmey J.C.; Deering T.G.; Keller S.R.; Maier B.; Mirmira, R.G. Peroxisome proliferator-activated receptor $\gamma$ activation restores islet function in diabetic mice through reduction of endoplasmic reticulum stress and maintenance of euchromatin structure. Mol. Cell Biol., 2009, 29(8), 2053-67.

[66] Christensen, D.P.; Dahllöf, M.; Lundh, M.; Rasmussen, D.N Nielsen, M.D.; Billestrup, N.; Grunnet, L.G.; Mandrup-Poulsen, T. Histone deacetylase (HDAC) inhibition as a novel treatment for diabetes mellitus. Mol. Med., 2011, 17(5-6), 378.

[67] Soupart, A.; Coffernils, M.; Couturier, B.; Gankam-Kengne, F.; Decaux, G. (2012). Efficacy and tolerance of urea compared with vaptans for long-term treatment of patients with SIADH. Clin. $J$. Am. Soc. Nephrol., 2012, 7(5), 742-7.

[68] Sinz, C.; Chang, J.; Lins, A. R.; Brady, E.; Candelore, M.; DallasYang, Q.; Ding, V.; Jiang, G.; Lin, Z.; Mock, S.; Qureshi, S.; Salituro, G.; Saperstein, R.; Shang, J.; Szalkowski, D.; Tota, L.; Vincent, S.; Wright, M.; Xu, S.; Yang, X.; Zhang, B.; Tata, J.; Kim, R.; Parmee, E. (2011). Discovery of cyclic guanidines as potent, orally active, human glucagon receptor antagonists. Bioorg Med. Chem. Lett., 2011, 21(23), 7131-6.

[69] Kawai, K.; Kato, T.; Mori, H.; Kitamura, J.; Nozawa, Y. A comparative study on cytotoxicities and biochemical properties of anthraquinone mycotoxins emodin and skyrin from Penicillium islandicum Sopp. Toxicol. Lett., 1984, 20(2),155-60.

\begin{tabular}{lrr}
\hline Received: September 06, 2014 & Revised: October 08, 2014 & Accepted: October 12, 2014 \\
(C) Lotfy et al.; Licensee Bentham Open. & &
\end{tabular}

(C) Lotfy et al.; Licensee Bentham Open.

This is an open access article licensed under the terms of the Creative Commons Attribution Non-Commercial License (http://creativecommons.org/licenses/by-nc/3.0/) which permits unrestricted, non-commercial use, distribution and reproduction in any medium, provided the work is properly cited. 